Check for updates

Cite this: Mater. Adv., 2021 2, 488

Received 29th November 2020 Accepted 13th December 2020

DOI: 10.1039/d0ma00935k

rsc.li/materials-advances

\title{
M13 bacteriophage-templated gold nanowires as stretchable electrodes in perovskite solar cells $\dagger$
}

\author{
Jiye Han, $\ddagger^{\mathrm{ab}}$ Jeong-Seok Nam, (D) $\ddagger^{\mathrm{b}}$ Kyusun Kim, ${ }^{\mathrm{b}}$ Eun Jung Choi, ${ }^{\mathrm{c}}$ Jong- \\ Min Lee, (D) ${ }^{c}$ Shigeo Maruyama, (D) de II Jeon (D)*bd and Jin-Woo Oh (D)*ac
}

\begin{abstract}
The synthesis and stretchable device application of bacteriophage-templated gold nanowires are demonstrated. Stretchable gold nanowires are synthesised by growing gold nanoparticles on a network of virus clones. Exploiting dimethylamine borane as a reducing agent, a spontaneous redox reaction between $\mathrm{HAuCl}_{4}$ and $\mathrm{M} 13$ bacteriophage wild-type virus-without the need for genetic engineering-produces a metal nanowire network with high transparency and conductivity. Virus, $\mathrm{HAuCl}_{4}$, and ascorbic acid additive concentrations are optimised for high optical conductivity. The optimal virus-templated gold nanowire electrodes from aqueous solutions exhibit a sheet resistance of $144.5 \Omega \mathrm{sq}^{-1}$ and transparency of $83 \%$ at $550 \mathrm{~nm}$ light wavelength. The virus-templated gold nanowire electrodes are transferred to polydimethylsiloxane for morphology roughness reduction as well as the application of its stretchability. Perovskite solar cells fabricated using virus-templated Au nanowires exhibit a power conversion efficiency of $9.28 \%$ and a stretchability of $8 \%$ owing to the intrinsic flexibility of the M13 bacteriophage template.
\end{abstract}

\section{Introduction}

The application of natural or nature-inspired synthetic biomaterials to electronics is a promising research field in the light of current plastic pollution and raw material shortage problems. ${ }^{1,2}$ The M13 bacteriophage is an environmentally friendly biomaterial, which has readily been used in electronics. ${ }^{3-10}$ In particular, the application of the M13 bacteriophage as a template for the assembly of conductive materials has attracted great attention. ${ }^{11-16}$ The M13 bacteriophage has a structure of single-stranded deoxyribonucleic acid (DNA) enclosed in a cylindrical capsid with 2700 copies of the PVIII protein and 5 copies of the pIII protein, resulting in 5 -fold symmetry along the length of the virus. The pVIII proteins are oriented in such a way that the surface of the virus has both

\footnotetext{
${ }^{a}$ Department of Nano Fusion Technology, Pusan National University, 63-2 Busandaehak-ro, Busan, 46241, South Korea. E-mail: ojw@pusan.ac.kr

${ }^{b}$ Department of Chemistry Education, Graduate School of Chemical Materials, Institute for Plastic Information and Energy Materials, Pusan National University, 63-2 Busandaehak-ro, Busan 46241, South Korea

${ }^{c}$ Bio-IT Fusion Technology Research Institute, Pusan National University, 63-2 Busandaehak-ro, Busan 46241, South Korea

${ }^{d}$ Department of Mechanical Engineering, School of Engineering,

The University of Tokyo, Tokyo 113-8656, Japan. E-mail: il.jeon@spc.oxon.org

${ }^{e}$ Energy NanoEngineering Lab., National Institute of Advanced Industrial Science and Technology (AIST), Tsukuba 305-8564, Japan

$\dagger$ Electronic supplementary information (ESI) available. See DOI: 10.1039/ d0ma00935k

\# J. H. and J.-S. N. contributed equally to this work.
}

peptide termini, i.e., amino and carboxyl ends. Such characteristics make the M13 bacteriophage an excellent template for the synthesis of various functional nanowires as the carboxylate ends of the virus have an affinity for cationic metal particle binding and nucleation along the shaft of a virus. ${ }^{17,18}$ The flexible and filamentous M13 bacteriophage, with a high aspect ratio of approximately $6.5-880 \mathrm{~nm}$ is capable of forming electrodes with a large metal-coated network. ${ }^{3,4}$

In the wake of sustainable society, organometallic halide perovskite solar cells (PSCs) have emerged as a next-generation energy-harvester. ${ }^{19}$ As the paradigm of electronics is shifting to stretchable devices at the level of artificial skin and healthmonitoring plasters, ${ }^{20}$ energy devices such as PSCs are following suit. Accordingly, research on low-cost and stretchable PSCs has progressed greatly in recent years, and it has been found that transparent conductors hold the key to the performance of stretchable and flexible PSCs. ${ }^{21-23}$ It is imperative that highcost and inflexible metal oxide transparent conductors of PSCs are replaced by a low-cost and stretchable alternative. In this respect, carbon-based transparent conductors have shown promising potential. ${ }^{24-28}$ However, their conductivity has limitations and the use of chemical dopants has a stability issue. ${ }^{29,30}$ Moreover, most reported carbon electrodes are not solutionprocessable. Those that are solution-processable, such as reduced graphene oxide ${ }^{31}$ and double-walled carbon nanotubes, ${ }^{23}$ display limited performance. Metal nanowire electrodes, on the other hand, have the upper hand as they are solution-processable ${ }^{23,32-34}$ and highly conductive. ${ }^{35-37}$ However, their mechanical flexibility 
is low as metals are stiff and ductile. While nanowire entanglement may give rise to flexibility, a single string of metal wire can only stretch so far without being damaged or cut. ${ }^{38-40}$ Thus, it is essential that stretchable metal nanowire shafts are developed. The M13 bacteriophage, in this sense, can satisfy the need for a stretchable nanowire template. In fact, there have been a few M13 bacteriophage-templated electrodes reported to date. ${ }^{12-15,41-44}$ However, there are no reports on M13 bacteriophage-based stretchable transparent electrodes or their application to PSCs. Furthermore, the previous approach to M13 bacteriophage-templated electrodes required illumination ${ }^{45}$ or genetic engineering $^{13,46,47}$ during synthesis. For example, an evolutionary screening process called bio-panning was used to selectively bind gold particles. ${ }^{17}$

In this study, we demonstrate the synthesis of environmentally friendly and scalable M13 bacteriophage-templated stretchable electrodes and their application as a transparent conductor in PSCs. Neither a diameter control ${ }^{48}$ nor a temperature control $^{49}$ was necessary for the M13 bacteriophagetemplated metal nanowire synthesis. Wild-type M13 bacteriophages were used directly to induce the reduction reaction of gold nanoparticles for the binding process using two commonly used reducing agents, sodium borohydride $\left(\mathrm{NaBH}_{4}\right)^{50-52}$ and dimethylamine borane (DMAB). ${ }^{53-55}$ The concentrations of viruses, gold particles, and ascorbic acid additive were optimised for comparison. The optical conductivity of the virus-templated gold nanowire electrodes using $\mathrm{NaBH}_{4}$ was far superior to those using DMAB. The reason behind this performance difference was the formation of $\mathrm{NaCl}$ impurities and the rate of reaction. The resulting virus-templated Au nanowire electrode exhibited a sufficient optical conductivity of $144.5 \Omega \mathrm{sq}^{-1}$ with $83 \%$ transparency at $550 \mathrm{~nm}$, which changed to $158.1 \Omega \mathrm{sq}^{-1}$ and $76 \%$ after the polydimethylsiloxane (PDMS) imprint transfer to alleviate the mal-effect of the rough morphology. The stretchable electrodes showed an excellent stretchability of $11 \%$ (change in resistance over original resistance of the film $(\Delta R / R))$. PSCs were fabricated based on the stretchable virustemplated electrodes, which gave a power conversion efficiency (PCE) of $9.28 \%$ with negligible hysteresis and device stretchability of $8 \%$. This performance is one of the highest among the reported stretchable metal nanowire-based PSCs.

\section{Results and discussion}

Virus-templated nanowires were fabricated by growing metal particles on wild-type M13 bacteriophage in water and dropcasting the solution onto glass substrates, which were later transferred onto polydimethylsiloxane (PDMS) for device application as stretchable electrodes (Fig. 1). The wild-type M13 bacteriophage possesses amino acids with carboxylate ends, namely, aspartate and glutamate. These functional groups are known to bind to positive metal ions via ion exchange. ${ }^{56}$ Initially, we tried to bind silver metal particles to the M13 bacteriophages to produce virus-templated $\mathrm{Ag}$ nanowires. Varying amounts of $\mathrm{AgNO}_{3}$ were added to the aqueous M13 bacteriophage solution at different concentrations. This was followed by the addition of ascorbic acid, which has been reported to help metal growth, ${ }^{57-65}$ and reducing agents, ${ }^{66-76}$ which promote the reduction of the added metal ions. However, the virus-templated Ag nanowire electrodes did not exhibit any conductivity (Fig. S1, ESI $\dagger$ ). Bio-transmission electron microscopy (bio-TEM) images confirm that the virus network forms a nice nanowire (Fig. S2, ESI $\dagger$ ). This indicates that the reason for the lack of conductivity is that the wild-type M13 bacteriophages do not have sufficient ionic interaction strength to bind to Ag nanoparticles as strongly as to Au nanoparticles. ${ }^{77}$ This explains why previous studies report genetically modified $4 \mathrm{E}$ virus - not the wild-type-when producing virus-templated Au nanowire electrodes. ${ }^{45}$

Virus-templated $\mathrm{Au}$ nanowire electrodes had drastically higher conductivity and transparency than their $\mathrm{Ag}$ nanowire electrode counterparts. Fig. 2 and Fig. S3 (ESI $\dagger$ ) show the sheet resistance of virus-templated $\mathrm{Au}$ nanowire electrodes on glass measured using the 4 probe method over the virus, $\mathrm{HAuCl}_{4}$, and ascorbic acid (AA) concentrations under two different reducing agents, namely, 4-(dimethylamino)benzaldehyde (DMAB) (eqn (1)) and (eqn (2)) and $\mathrm{NaBH}_{4}$ (eqn (3)). Fig. 2a and $b$ show the resistance of the electrodes when $0.5 \mathrm{~mol} \mathrm{~L}^{-1}$ $\mathrm{HAuCl}_{4}$ was used without AA. The results reveal that the amount of virus affects the sheet resistance greatly. It is interesting that the sheet resistance values of the virus-based electrodes were significantly lower when DMAB rather than $\mathrm{NaBH}_{4}$ was used as a reducing agent. A relatively small amount
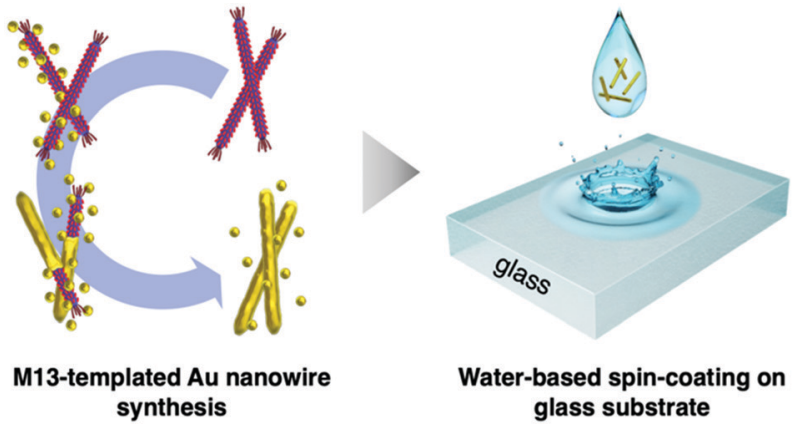
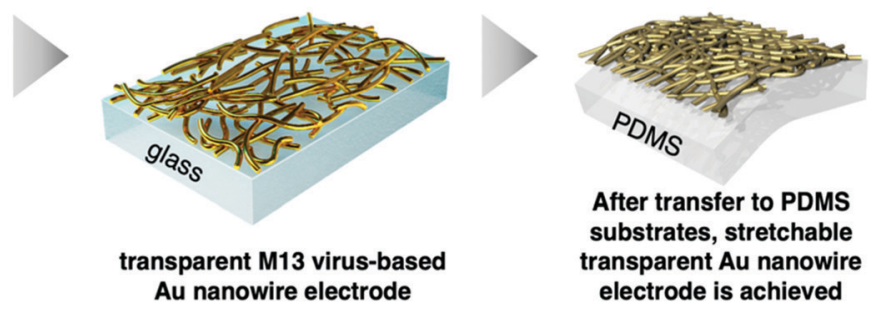

After transfer to PDMS substrates, stretchable transparent Au nanowire electrode is achieved

Fig. 1 Schematic illustration of the growth, thin-film fabrication, and transfer of the M13 bacteriophage-templated gold nanowire for stretchable electrode applications. 

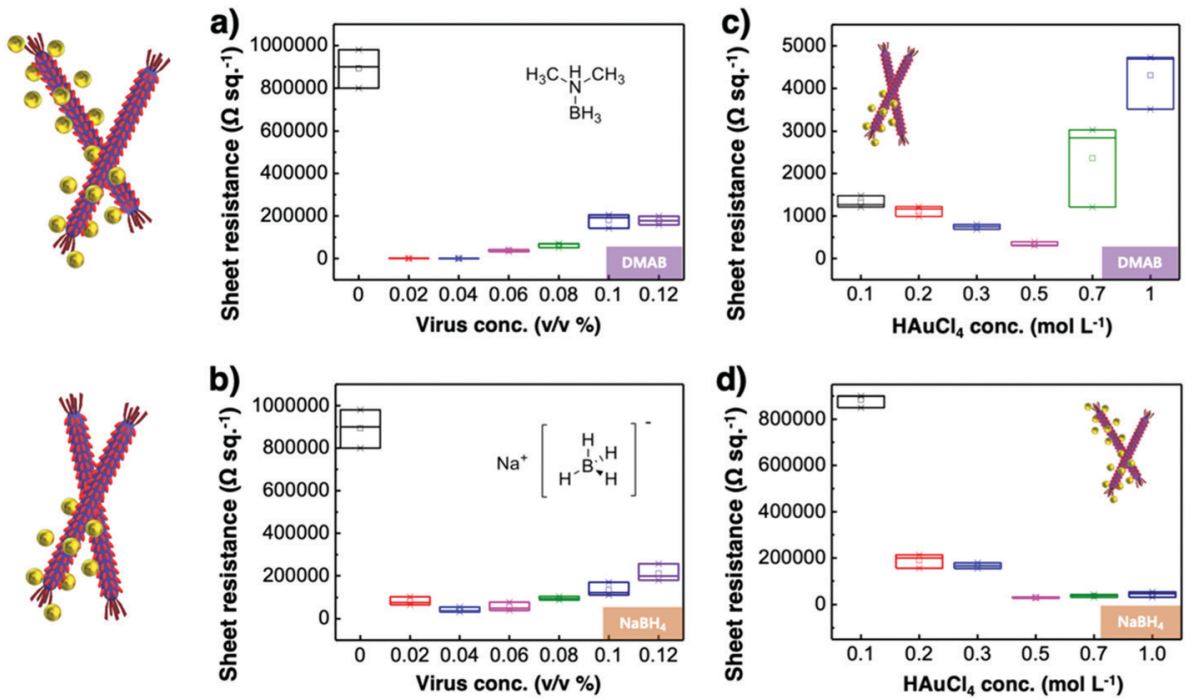
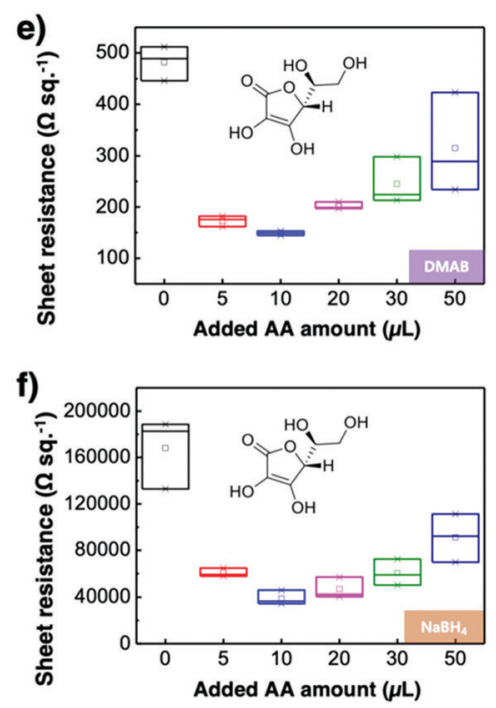

Fig. 2 Sheet resistance according to (a) and (b) virus concentrations, (c) and (d) $\mathrm{HAuCl}_{4}$ concentrations, and (e) and (f) AA concentrations under DMAB and $\mathrm{NaBH}_{4}$ reducing agents.

of the M13 virus $(0.04 \% \mathrm{v} / \mathrm{v})$ was optimal with both DMAB and $\mathrm{NaBH}_{4}$. This is because the M13 bacteriophages themselves are insulators and serve only as a growth template for metal ions. Changing the amount of $\mathrm{HAuCl}_{4}$ influenced the overall sheet resistance as well, though at a relatively lesser degree. While increasing concentration decreased sheet resistance, $0.5 \mathrm{~mol} \mathrm{~L}^{-1}$ was found to be the optimal concentration for both DMAB and $\mathrm{NaBH}_{4}$ (Fig. 2c and d). Adding AA decreased sheet resistance even further. The optimal AA concentration was $10 \mu \mathrm{L}$, which resulted in sheet resistance of approximately 144.5 and $36500 \Omega \mathrm{sq}^{-1}$ for the DMAB-added and $\mathrm{NABH}_{4}$-added virustemplated Au nanowires, respectively.

$$
\begin{aligned}
& \mathrm{HAuCl}_{4}+\left(\mathrm{CH}_{3}\right)_{2} \mathrm{NHBH}_{3}+3 \mathrm{H}_{2} \mathrm{O} \stackrel{k_{1}}{\longrightarrow} \mathrm{Au} \downarrow \\
&+\mathrm{H}_{3} \mathrm{BO}_{3}+4 \mathrm{HCl}+\left(\mathrm{CH}_{3}\right)_{2} \mathrm{NH}+\frac{3}{2} \mathrm{H}_{2} \uparrow \\
& \mathrm{HAuCl}_{4}+\left(\mathrm{CH}_{3}\right)_{2} \mathrm{NHBH}_{3}+3 \mathrm{H}_{2} \mathrm{O}+\mathrm{Au} \stackrel{k_{2}}{\longrightarrow} 2 \mathrm{Au} \downarrow \\
&+\mathrm{H}_{3} \mathrm{BO}_{3}+4 \mathrm{HCl}+\left(\mathrm{CH}_{3}\right)_{2} \mathrm{NH}+\frac{3}{2} \mathrm{H}_{2} \uparrow
\end{aligned}
$$

$$
\mathrm{HAuCl}_{4}+\mathrm{NaBH}_{4} \rightarrow \mathrm{Au}^{0}+\mathrm{B}(\mathrm{OH})_{3}+\mathrm{NaCl}+\mathrm{H}_{3} \mathrm{O}^{+}
$$

Bio-TEM images show the virus-templated Au nanowire network, the effect of the type of reducing agent, M13 bacteriophage concentration, and $\mathrm{HAuCl}_{4}$ concentration. Both the virustemplated $\mathrm{Au}$ nanowires made by $\mathrm{DMAB}$ and $\mathrm{NaBH}_{4}$ show a well-connected nanowire network, but those made by DMAB show particles around the network (Fig. S4, ESI†). Delving further into the study, bio-TEM images with different virus concentrations show that Au particles have a round shape, and an increase in the virus concentration decreases the number of particles (Fig. S5, ESI $\dagger$ ). Increasing the $\mathrm{HAuCl}_{4}$ concentration increases the round-shaped particles around the network
(Fig. S6, ESI †). Energy-dispersive X-ray spectroscopy (EDS) analysis confirms that the virus nanowires were fully covered by $\mathrm{Au}$ (Fig. 3a). On the other hand, the virus-templated $\mathrm{Au}$ nanowire made by $\mathrm{NaBH}_{4}$ contains cubic particles, which are mixed with circular Au particles (Fig. S7, ESI $\dagger$ ). From the EDS analysis, we suspect that these particles are $\mathrm{NaCl}$, which is the reason for the poor optical conductivity of the virus-templated Au nanowires made by $\mathrm{NaBH}_{4}$ (Fig. 3b) (eqn (3)).

$\mathrm{X}$-Ray diffraction spectroscopy (XRD) was used to analyse the virus-templated Au nanowires. The XRD spectrum of $\mathrm{HAuCl}_{4}$ mixed with DMAB shows peaks corresponding to $\mathrm{Au}$ (Fig. 3c and Fig. S8, ESI $\dagger$ ), which intensify upon the addition of the M13 bacteriophage, proving that the presence of the M13 virus enhances $\mathrm{Au}$ formation. In the case of the virus-templated Au nanowires made by $\mathrm{NaBH}_{4}$, a mixture of $\mathrm{HAuCl}_{3}$ and $\mathrm{NaBH}_{4}$ formed not only Au but also $\mathrm{NaCl}$, as evidenced by both XRD and EDS (Fig. 3b, d, and Fig. S9, ESI $\dagger$ ) (eqn (3)). The presence of the M13 virus enhanced the intensity of the $\mathrm{Au}$ peaks as expected, and the suppression of the $\mathrm{NaBH}_{4}$ peaks upon the addition of the M13 viruses corroborates this (Fig. S10, ESI $\dagger$ ). This reveals that the nanoparticle growth of the M13 viruses is not as good when $\mathrm{NaBH}_{4}$ is used as a reducing agent.

X-Ray photoelectron spectroscopy (XPS) was used to investigate the chemistry occurring within the virus-templated $\mathrm{Au}$ nanowires. The $\mathrm{Au}$ if peaks of the $\mathrm{HAuCl}_{4}+\mathrm{DMAB}$ mixture and the M13 virus $+\mathrm{HAuCl}_{4}+\mathrm{DMAB}$ mixture show that the intensity of the $\mathrm{Au} 4 \mathrm{f}_{7 / 2}$ peak, which corresponds to $\mathrm{Au}(0)$ metal particles, increases upon the addition of the M13 virus (Fig. 4a and Fig. S11, ESI $\dagger$ ). ${ }^{78-80}$ At the same time, the $\mathrm{Au} 4 \mathrm{f}_{5 / 2}$ peak convolution between $86 \mathrm{eV}(\mathrm{Au}(\mathrm{I}))$ and $87 \mathrm{eV}(\mathrm{Au}(\mathrm{III}))$ as well as the peak at $91 \mathrm{eV}$, which corresponds to $\mathrm{Au}(\mathrm{I} \& \mathrm{III})$, decreased upon the addition of the M13 virus, indicating the transition of $\mathrm{HAuCl}_{4}$ to Au particles. On the other hand, the Au $4 \mathrm{f}$ peaks of the $\mathrm{HAuCl}_{4}+\mathrm{NaBH}_{4}$ mixture and the $\mathrm{M} 13$ virus $+\mathrm{HAuCl}_{4}+$ $\mathrm{NaBH}_{4}$ mixture show that the intensity of the $\mathrm{Au} 4 \mathrm{f}_{7 / 2}$ peak 


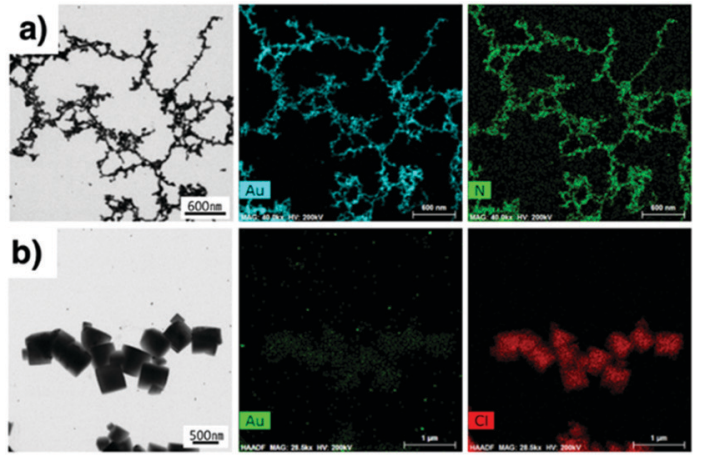

c)

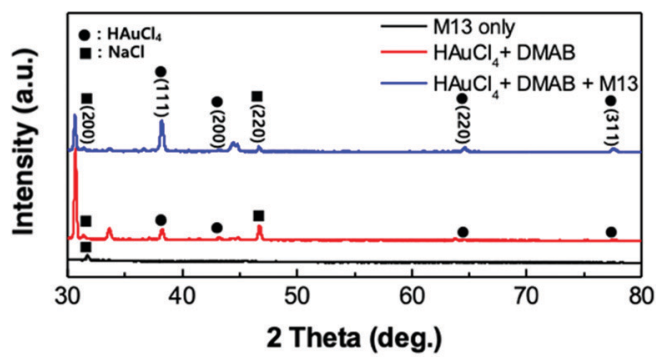

d)

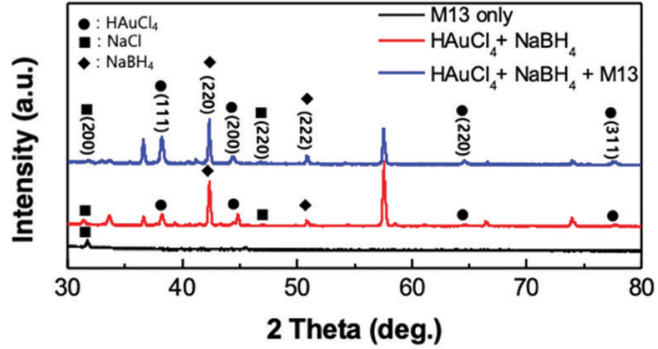

Fig. 3 STEM images and EDS analysis of the virus-templated Au nanowires formed under (a) DMAB and (b) $\mathrm{NaBH}_{4}$. XRD spectra of the virus-templated Au nanowires formed under (c) DMAB and (d) $\mathrm{NaBH}_{4}$.

increases slightly, which indicates that Au particles are generated in a relatively small quantity (Fig. $4 \mathrm{~b}$ and Fig. S11, ESI $\dagger$ ). A decrease in the peaks responsible for $\mathrm{Au}(\mathrm{I})$ and $\mathrm{Au}(\mathrm{II})$ was observed, but to a smaller degree compared to that in the case of DMAB. This confirms our finding from TEM and XRD that a greater amount of Au particles was generated when DMAB was used as a reductant as opposed to $\mathrm{NaBH}_{4}$. The $\mathrm{Cl} 2 \mathrm{p}$ peaks are composed of two species, namely $\mathrm{Cl} 2 \mathrm{p}_{3 / 2}$ at $197.6 \mathrm{eV}$, which represents adsorbed chloride ions on metals, ${ }^{81,82}$ and $\mathrm{Cl} 2 \mathrm{p}_{1 / 2}$ at $199.3 \mathrm{eV}$, which represents reduced $\mathrm{Cl}$ ions, such as $\mathrm{HCl}^{83,84}$ The $\mathrm{Cl} 2 \mathrm{p}_{3 / 2}$ peak decreases while the $\mathrm{Cl} 2 \mathrm{p}_{1 / 2}$ peak increases upon the addition of the M13 virus to a mixture of $\mathrm{HAuCl}_{4}$ and DMAB, indicating that the reduction of $\mathrm{Cl}$ in $\mathrm{HAuCl}_{4}$ has taken place (Fig. 4c and Fig. S12, ESI $\dagger$ ). However, there is no change in the $\mathrm{HAuCl}_{4}$ and $\mathrm{NaBH}_{4}$ mixture in the presence of the M13 virus (Fig. $4 \mathrm{~d}$ and Fig. S12, ESI $\dagger$ ). The position of the $\mathrm{N} 1 \mathrm{~s}$ peaks reveals the M13 viruses functioning as a template for the $\mathrm{Au}$ particles as the peak shifts to a higher binding energy when there are elements attached to the virus surface. Both the virustemplated $\mathrm{Au}$ nanowires with $\mathrm{DMAB}$ and $\mathrm{NaBH}_{4}$ manifest upshifts of $\mathrm{N} 1$ s peaks, yet a greater peak shift is observed for the DMAB-added system over the $\mathrm{NaBH}_{4}$-added system,
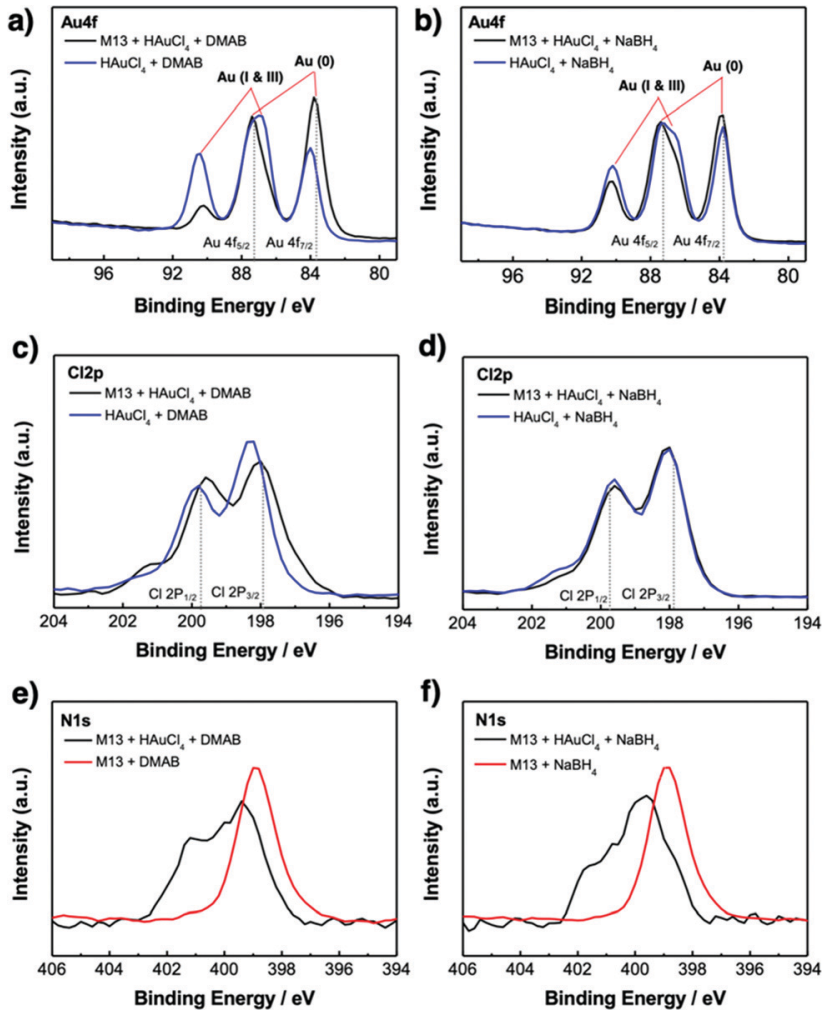

Fig. 4 XPS measurements of $\mathrm{Au} 4 \mathrm{f}$ peaks of the virus-templated $\mathrm{Au}$ nanowires made under (a) DMAB or (b) $\mathrm{NaBH}_{4}$ (blue). (c) $\mathrm{Cl} 2 \mathrm{p}$ peaks of the virus-templated Au nanowires made under (c) DMAB or (d) $\mathrm{NaBH}_{4} . \mathrm{N}$ 1s peaks of the virus-templated $A u$ nanowires made under (e) DMAB and (f) $\mathrm{NaBH}_{4}$

confirming a stronger interaction at the virus surface (Fig. 4e and f). ${ }^{85}$ Both DMAB and $\mathrm{NaBH}_{4}$ contain boron. XPS profiles show that the boron species disappeared upon the addition of $\mathrm{HAuCl}_{4}$ (Fig. S13, ESI $\dagger$ ). This evidences that a reaction took place, but we are unsure as to why boron cannot be detected after the reaction (eqn (1)), (eqn (2)), and (eqn (3)). As evidenced by various analyses thus far, the Au-binding M13 bio-template under DMAB enabled a higher yield synthesis of Au nanowires than under $\mathrm{NaBH}_{4}$. We conjecture that one of the reasons for this can be found in the chemical reaction mechanism. Barring the formation of $\mathrm{NaCl}$, the reaction between $\mathrm{HAuCl}_{4}$ and $\mathrm{NaBH}_{4}$ is generally a one-step quick reaction with a relatively weak reducing power of $\mathrm{NaBH}_{4}$ (eqn (3)). ${ }^{50-52}$ However, being a much stronger reducing agent than $\mathrm{NaBH}_{4}, \mathrm{DMAB}$ induces faster reaction kinetics and forms $\mathrm{Au}$ at a higher growth rate (eqn (1)) and (eqn (2)). ${ }^{53-55}$ The greater growth rate than etching rate due to $\mathrm{Cl}$ ions indicates that when DMAB is used as a reducing agent, the Au nanowire quality is bound to be high. ${ }^{86}$ In addition to this, reduction with $\mathrm{NaBH}_{4}$ favours alkaline conditions, whereas reduction with DMAB favours acidic conditions. Since the solution turns acidic when we add $\mathrm{HAuCl}_{4}$ and the reduction reaction by DMAB produces $\mathrm{H}_{3} \mathrm{BO}_{3}$, the conditions stay acidic throughout the reaction which favours DMAB over $\mathrm{NaBH}_{4} \cdot{ }^{87}$

Photoelectron yield spectroscopy (PYS) was used to analyse the work function of the DMAB-added virus-templated $\mathrm{Au}$ 
nanowires and bare M13 viruses (Fig. S14a, ESI $\dagger$ ). The bare M13 viruses have a work function of $6.0 \mathrm{eV}$. However, the DMABadded virus-templated $\mathrm{Au}$ nanowires have a work function of approximately $5.3 \mathrm{eV}^{23,88}$ We suspect the mixture of $\mathrm{Au}(0)+$ $\mathrm{Au}(\mathrm{I})+\mathrm{Au}(\mathrm{III})$ in the M13 virus-templated $\mathrm{Au}$ nanowires leads to $5.3 \mathrm{eV}$ instead of $5.0 \mathrm{eV}$. This confirms the presence of $\mathrm{Au}$ nanoparticles on the viruses as well as the fact that the virustemplated $\mathrm{Au}$ nanowires have a good work function value for use as a transparent electrode in PSCs.

The morphology of the virus-templated Au nanowires was analysed using atomic force microscopy (AFM). The virus-templated $\mathrm{Au}$ nanowires on glass substrates showed micrometre-scale roughness due to the random stacking of the nanowires (Fig. 5a). To reduce the roughness and enable stretchable device application, the nanowires were transferred to PDMS films by a stamping method. The embedded nanowires exhibited an average roughness $\left(R_{\mathrm{a}}\right)$ of $43 \mathrm{~nm}$. The roughness was further reduced to $1.2 \mathrm{~nm}$ by applying poly(triaryl amine) (PTAA) on top (Fig. S15, ESI $\dagger$ ). Such roughness values are sufficiently low for the fabrication of PSCs. The conductivity and transmittance were retained after transferring to the stretchable PDMS substrate (Fig. S16, ESI $\dagger$ ). The optical
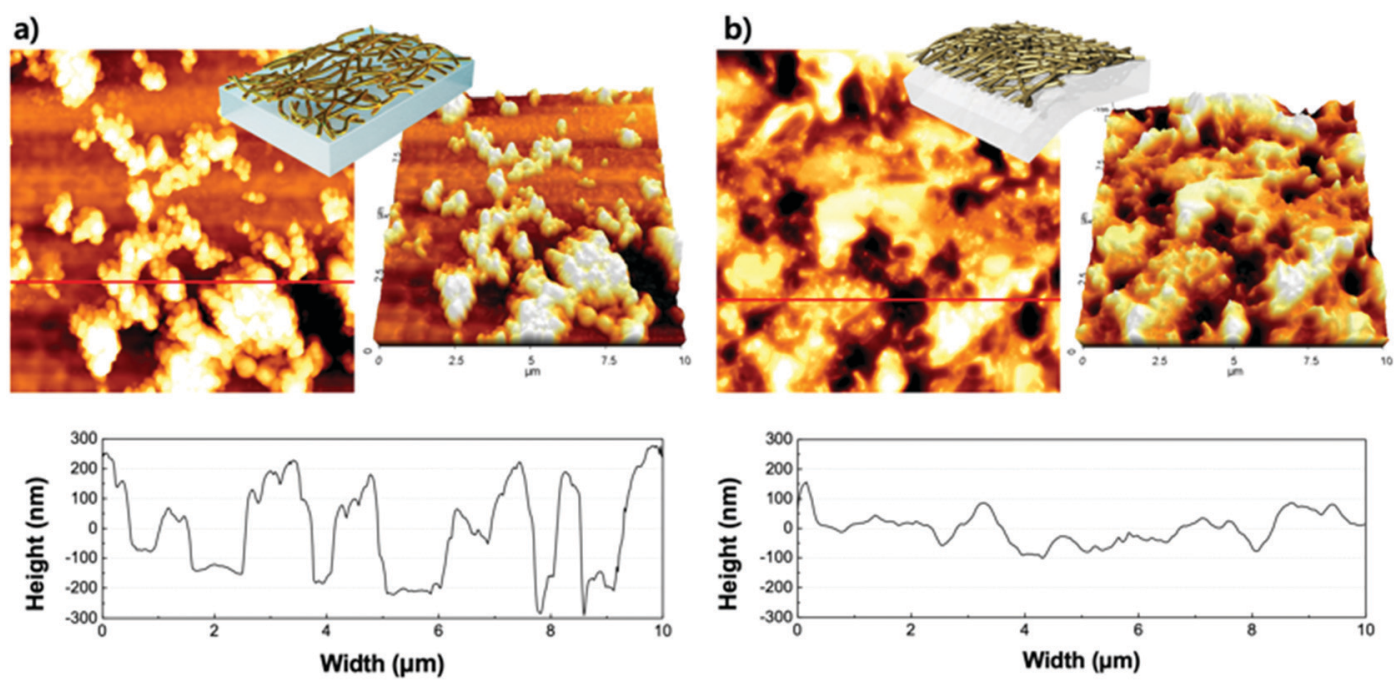

Fig. 5 AFM images $\left(10 \times 10 \mu \mathrm{m}^{2}\right)$ of M13 bacteriophage-templated Au nanowires on (a) glass, and (b) the surface after transfer to PDMS.
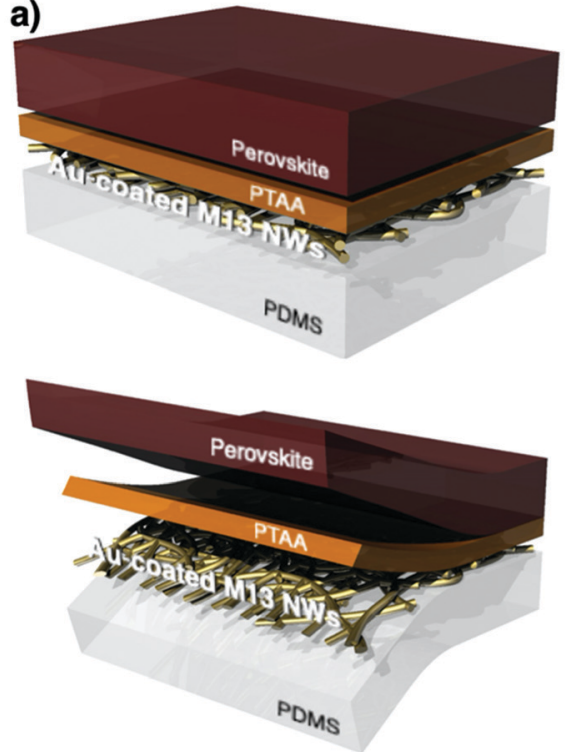

b)

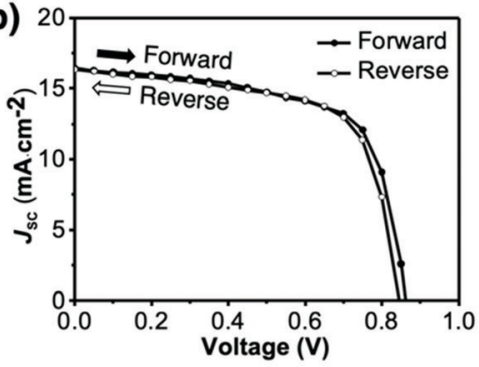

d)

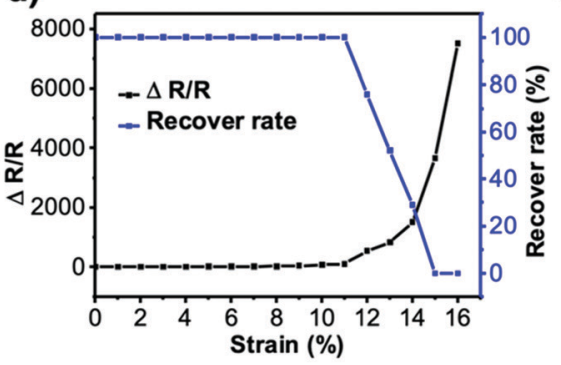

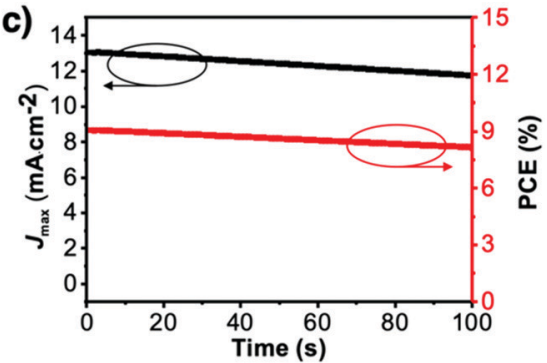

e)

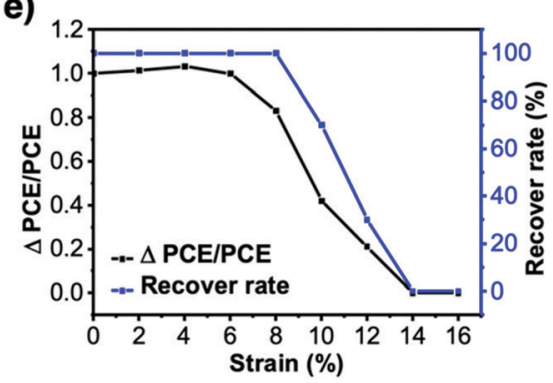

Fig. 6 (a) Illustrations of the virus-templated Au nanowires on PDMS with PTAA and perovskite layers coated on top. (b) $J-V$ curves of the virustemplated Au nanowire-based stretchable PSC under forward and reverse bias. (c) MPPT data of the of the virus-templated Au nanowire-based stretchable PSC. (d) Stretchability data of the virus-templated Au nanowire electrode. (e) Stretchability data of the virus-templated Au nanowire-based PSC. 
Table 1 Photovoltaic parameters of the virus-templated Au nanowirebased stretchable PSCs under 1 sun (AM1.5G, $100 \mathrm{~mW} \mathrm{~cm}^{-2}$ )

\begin{tabular}{|c|c|c|}
\hline & Forward & Reverse \\
\hline$V_{\mathrm{OC}}(\mathrm{V})$ & 0.86 & 0.85 \\
\hline$J_{\mathrm{SC}}\left(\mathrm{mA} \mathrm{cm}{ }^{-2}\right)$ & 13.1 & 13.3 \\
\hline $\mathrm{FF}$ & 0.66 & 0.66 \\
\hline PCE (\%) & 9.28 & 9.11 \\
\hline Hysteresis index & 0.021 & \\
\hline
\end{tabular}

Table 2 Reported PCEs of metal nanowire electrode-based PSCs

\begin{tabular}{llcl}
\hline Year & Material type & PCE $(\%)$ & Ref. \\
\hline 2016 & $\mathrm{Ag}$ & 8.44 & 89 \\
2017 & $\mathrm{Cu}$ & 8.65 & 90 \\
2018 & $\mathrm{Cu} @ \mathrm{Ni}$ & 12.2 & 91 \\
2018 & $\mathrm{Ag}$ & 7.88 & 92 \\
2016 & $\mathrm{Ag} /$ graphene & 10.4 & 93 \\
2019 & $\mathrm{Ag} / \mathrm{GO}$ & 9.62 & 94 \\
2020 & $\mathrm{Au}$ & 9.28 & This work
\end{tabular}

conductivity of the virus-templated Au nanowires was slightly lower than the previously reported values of metal nanowires (Table S1 and Fig. S17, ESI $\dagger$ ). PSCs were fabricated in a structural configuration of $\mathrm{PDMS} /$ virus-templated $\mathrm{Au}$ nanowires/PTAA/ $/ \mathrm{MA}_{0.6} \mathrm{FA}_{0.4} \mathrm{PbI}_{2.9} \mathrm{Br}_{0.1} / \mathrm{C}_{60} /$ bathocuproine (BCP)/Au (Fig. 6a). The devices exhibited a PCE of $9.28 \%$ with negligible hysteresis (Fig. 6b and Fig. S18, S19, ESI; $\dagger$ and Table 1). Moreover, maximum power point tracking (MPPT) data showed a power output of $9.1 \%$, which was retained rather well over $100 \mathrm{~s}$ in air without encapsulation (Fig. 6c). The MPPT power output dropped rather fast. We attribute this to the humid atmosphere $(\mathrm{RH} \sim 60 \%)$ at the time and place of the measurement. According to our time-evolution of UV-vis absorption spectra shows that both the perovskite films on ITO and Au nanowires showed the same degradation rate (Fig. S20, ESI $\dagger$ ). Furthermore, a stretchability test was performed on both the virus-templated Au nanowire electrode and PSC (Fig. 6d and e). Fig. 6d shows that the electrode can stretch up to $10 \%$ strain without a decrease in conductivity, and it loses the ability to recover conductivity when stretched to more than $11 \%$ strain. Fig. 6e shows that the virus-templated Au nanowire-based PSC can be stretched axially up to $8 \%$ of its original dimension or width. The obtained PCE and stretchability is one of the best among the reported transparent nanowire electrode-based PSCs (Table 2 and Fig. S21, ESI $\dagger$ ). ${ }^{89-94}$

\section{Conclusions}

Although the photovoltaic performance of the virus-templated gold nanowire-based PSCs is less than ideal at this stage, the versatility and potential of the biologically synthesised metal nanowires are clear. Virus-templated nanowires function well with $\mathrm{Au}$ nanoparticles under DMAB reductant. The virus concentration, $\mathrm{HAuCl}_{4}$ concentration, and $\mathrm{AA}$ additive concentration were optimised to give a sheet resistance of $144.5 \Omega \mathrm{sq}^{-1}$ and $83 \%$ at $550 \mathrm{~nm}$ on glass. The nanowires were transferred to PDMS substrates to test their stretchable application, which resulted in a PCE of $9.28 \%$ and a stretchability of $8 \%$. This performance is one of the highest reported for stretchable metal nanowire-based PSCs and demonstrates the first stretchable biomaterial-templated electrode.

\section{Experimental}

\section{M13 bacteriophage synthesis}

The M13 bacteriophage was purchased from New England Biolabs (Ipswich, MA, USA). The product (M13KE, NEB \# N0316) was mass-produced according to the following protocol: the M13 bacteriophage was amplified in an Escherichia coli (E. coli, ER2738) culture and purified by precipitation using polyethylene glycol followed by dispersion. Then it was refined through a membrane with $0.45 \mu \mathrm{m}$ pores (Minisart ${ }^{\circledR}$ NML, Syringe Filter 16555), and centrifuged repeatedly. The accuracy of the cultured product was confirmed by DNA sequencing analysis (BIONICS, Seoul, Republic of Korea). The M13 bacteriophage concentration was measured using Nano-drop 2000 (Evolution 300, Thermo Fisher Scientific, Waltham, MA, USA). Previously reported formulae and absorbance spectral values were used for the concentration calculation. ${ }^{10}$

\section{Metal nanowire growth}

The M13 bacteriophage-templated stretchable and transparent electrodes were prepared by dispersing different concentrations of wild-type M13 bacteriophage in $1 \mathrm{~mL}$ of DI water $(0,0.02$, $0.04,0.06,0.08,0.1$, and $0.12 \% \mathrm{v} / \mathrm{v})$. Then, $0.5 \mathrm{M}$ targeting metal ion solution (gold(III) chloride hydrate, $\mathrm{HAuCl}_{4}$ or silver nitrate, $\mathrm{AgNO}_{3}$, Sigma Aldrich) was added to the prepared M13 bacteriophage solution. At this time, the concentrations of the metal ions in the M13 bacteriophage solution were $0.1,0.2,0.3,0.5$, 0.7 , and $1.0 \mathrm{~mol} \mathrm{~L}^{-1}$. Subsequently, $0,5,10,20,30$, and $50 \mu \mathrm{L}$ of $100 \mathrm{mM}$ ascorbic acid (AA, Sigma Aldrich) were added to the reaction mixture. Finally, after adding $10 \mu \mathrm{L}$ of $1 \mathrm{M}$ 4-(dimethylamino)benzaldehyde (DMAB, Sigma Aldrich) or $\mathrm{NaBH}_{4}$ (Sigma Aldrich) as a reducing agent, the mixture was reacted at $25{ }^{\circ} \mathrm{C}$ for $3 \mathrm{~h}$. The methods of synthesising silver and gold are the same.

\section{Substrate transfer}

After $50 \mu \mathrm{L}$ drop-casting of metal nanowires on a glass substrate, it was completely filmed in a vacuum dry oven $\left(60{ }^{\circ} \mathrm{C}\right.$ for $12 \mathrm{~h}$ ). Then, PDMS was poured into the nanowire film and hardened. When the glass substrate and PDMS were slowly separated, the metal nanowire film was fixed to the PDMS and peeled off the glass substrate.

\section{Device fabrication}

Pre-patterned ITO/glass substrates $\left(12 \Omega \mathrm{sq}^{-1}, 20 \times 20 \mathrm{~mm}^{2}\right)$ (AMG Tech) were cleaned through sonication in acetone, isopropyl alcohol, and deionised water for $15 \mathrm{~min}$ in that order and stored in a drying oven at $120{ }^{\circ} \mathrm{C}$ for $20 \mathrm{~min}$. PTAA solution 
was prepared by dissolving $8 \mathrm{mg}$ of PTAA (Sigma Aldrich) in $1 \mathrm{~mL}$ of 2,3,5,6-tetrafluoro-7,7,8,8-tetracyanoquinodimethane (F4 TCNQ) solution, which was prepared by dissolving F4 TCNQ in chlorobenzene (Sigma Aldrich) at a concentration of $1 \mathrm{wt} \%$. Then, the PTAA layer was formed by spin-coating the solution on the DWNT (or ITO) substrates at $4000 \mathrm{rpm}$ for $30 \mathrm{~s}$ followed by annealing on a hotplate at a temperature of $100{ }^{\circ} \mathrm{C}$ for $10 \mathrm{~min}$. To obtain a reproducible coating of the perovskite film on the hydrophobic PTAA layer, poly[(9,9-bis $(30-((N, N-$ dimethyl)- $N$-ethylammonium)-propyl)-2,7-fluorene)-alt-2,7-(9,9dioctylfluorene)]dibromide (PFN-P2) (1-Material) was introduced as an interfacial compatibilizer. Its precursor solution was prepared by dissolving PFN-P2 in methanol with a concentration of $0.4 \mathrm{mg} \mathrm{mL}^{-1}$ and spin-coated on the PTAA layer at $4000 \mathrm{rpm}$ for $20 \mathrm{~s}$. Perovskite layer with a composition of $\mathrm{MA}_{0.6} \mathrm{FA}_{0.4} \mathrm{PbI}_{2.9} \mathrm{Br}_{0.1}$ precursor solution was prepared by dissolving $461 \mathrm{mg}$ of $\mathrm{PbI}_{2}$ (Tokyo Chemical Industry), $79.5 \mathrm{mg}$ of methylammonium iodide (Tokyo Chemical Industry), $68.8 \mathrm{mg}$ of formamidinium iodide (Tokyo Chemical Industry), $11.2 \mathrm{mg}$ of methylammonium bromide (Sigma Aldrich), and $75 \mu \mathrm{L}$ of urea-added dimethylsulfoxide (DMSO) (Sigma Aldrich) in $0.55 \mathrm{~mL}$ of $\mathrm{N}$-dimethylformamide (Sigma Aldrich). The urea solution was prepared by dissolving urea (Sigma Aldrich) in DMSO at a concentration of $44.4 \mathrm{mg} \mathrm{mL}^{-1}$ to induce large grain crystallisation of the perovskite film. The perovskite precursor solution was stirred for $1 \mathrm{~h}$ at room temperature. The solution was spin-coated at $4000 \mathrm{rpm}$ for $20 \mathrm{~s}$. Diethyl ether antisolvent (3-500 $\mu \mathrm{L})$ was applied $7 \mathrm{~s}$ after the beginning of the spincoating. A transparent film of perovskite intermediate phase was formed and changed into a black perovskite film after annealing at a temperature of $130{ }^{\circ} \mathrm{C}$ for $20 \mathrm{~min}$. The whole spin-coating process was conducted at a controlled temperature $\left(25{ }^{\circ} \mathrm{C}\right)$ and relative humidity $(<10 \%)$. Then $\mathrm{C}_{60}(20 \mathrm{~nm})$ and BCP $(6 \mathrm{~nm})$ layers were deposited through a square metal mask of $1.5 \times 1.5 \mathrm{~cm}^{2}$. Furthermore, a $\mathrm{Cu}$ electrode was deposited to complete devices with an area of $0.2 \times 0.2 \mathrm{~cm}^{2}$ $\left(0.04 \mathrm{~cm}^{2}\right)$ under a pressure of $<5.0 \times 10^{-6}$ torr inside a thermal evaporator.

\section{Material and device characterization}

$J-V$ curves of perovskite solar cells under light were measured using a source metre (Keithley 2400, Tektronix) at a step voltage of $20 \mathrm{mV}$ and a delay time of $50 \mathrm{~ms}$ in both the forward and reverse scan directions. AM1.5G illumination was simulated using a solar simulator (Sol3A Class, Oriel) with a KG-5-filtered silicon standard cell. $J-V$ curves under dark conditions were measured using a probe station built inside a dark-shield box. Grazing-incidence XRD $2 \theta$ scans were performed on a Jordan Valley D1 diffractometer using copper $K \alpha 1$ radiation and a parallel beam source. In the $2 \theta$ scans, the scattering angle $2 \theta$ between the incident beam and the diffracted beam changed, whereas the incident angle $\omega$ between the incident beam and the sample surface was fixed at $1^{\circ}$. Core-level photoemission measurements were performed by XPS (PerkinElmer, 5400MC) using monochromatic $\mathrm{Al} \mathrm{K} \alpha$ radiation. XPS resolution was estimated to be $1 \mathrm{eV}$, and the energy offset was calibrated using the surface C 1s peak. TEM measurements were conducted using high-resolution scanning/transmission electron microscopy (Talos F200X, FEI and H-7600, Hitachi). Optical transmittance and absorption spectra were obtained using a UV-visNIR spectrophotometer (V-570, JASCO). Surface topography measurements were conducted using an atomic force microscope (NX10, Park Systems) in non-contact mode. The van der Pauw method of four-probe measurement was conducted using a probe station and indium metal pieces.

\section{Conflicts of interest}

There are no conflicts to declare.

\section{Acknowledgements}

This work was supported by the Creative Materials Discovery Program of the National Research Foundation of Korea (NRF) funded by the Ministry of Science and ICT (NRF-2017M3D1A1039287), the Ministry of Education (NRF-2020R1A6A3A13075717), and the Korean government (NRF-2020R1G1A1101578). Part of this work was supported by JSPS KAKENHI Grant Numbers JP18H05329, JP20H00220, and by JST, CREST Grant Number JPMJCR20B5, Japan.

\section{Notes and references}

1 M. Irimia-Vladu, P. A. Troshin, M. Reisinger, L. Shmygleva, Y. Kanbur, G. Schwabegger, M. Bodea, R. Schwödiauer, A. Mumyatov, J. W. Fergus, V. F. Razumov, H. Sitter, N. S. Sariciftci and S. Bauer, Adv. Funct. Mater., 2010, 20, 4069.

2 M. Muskovich and C. J. Bettinger, Adv. Healthcare Mater., 2012, 1, 248.

3 C. Mao, Science, 2004, 303, 213.

4 B. Y. Lee, J. Zhang, C. Zueger, W.-J. Chung, S. Y. Yoo, E. Wang, J. Meyer, R. Ramesh and S.-W. Lee, Nat. Nanotechnol., 2012, 7, 351.

5 D. P. Pires, S. Cleto, S. Sillankorva, J. Azeredo and T. K. Lu, Microbiol. Mol. Biol. Rev., 2016, 80, 523.

6 J. M. L. Bernard and M. B. Francis, Front. Microbiol., 2014, 5,1 .

7 D.-M. Shin, H. J. Han, W.-G. Kim, E. Kim, C. Kim, S. W. Hong, H. K. Kim, J.-W. Oh and Y.-H. Hwang, Energy Environ. Sci., 2015, 8, 3198.

8 J.-W. Oh, W.-J. Chung, K. Heo, H.-E. Jin, B. Y. Lee, E. Wang, C. Zueger, W. Wong, J. Meyer, C. Kim, S.-Y. Lee, W.-G. Kim, M. Zemla, M. Auer, A. Hexemer and S.-W. Lee, Nat. Commun., 2014, 5, 3043.

9 J.-S. Moon, W.-G. Kim, D.-M. Shin, S.-Y. Lee, C. Kim, Y. Lee, J. Han, K. Kim, S. Y. Yoo and J.-W. Oh, Chem. Sci., 2017, 8, 921.

10 W.-J. Chung, J.-W. Oh, K. Kwak, B. Y. Lee, J. Meyer, E. Wang, A. Hexemer and S.-W. Lee, Nature, 2011, 478, 364. 
11 C. Mao, C. E. Flynn, A. Hayhurst, R. Sweeney, J. Qi, G. Georgiou, B. Iverson and A. M. Belcher, Proc. Natl. Acad. Sci. U. S. A., 2003, 100, 6946.

12 K. T. Nam, Science, 2006, 312, 885.

13 Y. J. Lee, H. Yi, W.-J. Kim, K. Kang, D. S. Yun, M. S. Strano, G. Ceder and A. M. Belcher, Science, 2009, 324, 1051.

14 F. Li and Q. Wang, Small, 2014, 10, 230.

15 M. Janczuk-Richter, I. Marinović, J. Niedziółka-Jönsson and K. Szot-Karpińska, Electrochem. Commun., 2019, 99, 11.

16 N. K. Petty, T. J. Evans, P. C. Fineran and G. P. C. Salmond, Trends Biotechnol., 2007, 25, 7.

17 Y. Huang, C.-Y. Chiang, S. K. Lee, Y. Gao, E. L. Hu, J. De Yoreo and A. M. Belcher, Nano Lett., 2005, 5, 1429.

18 S.-K. Lee, D. S. Yun and A. M. Belcher, Biomacromolecules, 2006, 7, 14.

19 N.-G. Park, M. Grätzel, T. Miyasaka, K. Zhu and K. Emery, Nat. Energy, 2016, 1, 16152.

20 J. Rogers, Z. Bao and T.-W. Lee, Acc. Chem. Res., 2019, 52, 521.

21 M. Park, H. J. Kim, I. Jeong, J. Lee, H. Lee, H. J. Son, D. Kim and M. J. Ko, Adv. Energy Mater., 2015, 5, 1501406.

22 B. J. Kim, D. H. Kim, Y.-Y. Lee, H.-W. Shin, G. S. Han, J. S. Hong, K. Mahmood, T. K. Ahn, Y.-C. Joo, K. S. Hong, N.G. Park, S. Lee and H. S. Jung, Energy Environ. Sci., 2015, 8, 916.

23 I. Jeon, J. Yoon, U. Kim, C. Lee, R. Xiang, A. Shawky, J. Xi, J. Byeon, H. M. Lee, M. Choi, S. Maruyama and Y. Matsuo, Adv. Energy Mater., 2019, 9, 1901204.

24 I. Jeon, R. Xiang, A. Shawky, Y. Matsuo and S. Maruyama, Adv. Energy Mater., 2019, 9, 1801312.

25 I. Jeon, Y. Matsuo and S. Maruyama, Top. Curr. Chem., 2018, 376, 4.

26 J. Yoon, H. Sung, G. Lee, W. Cho, N. Ahn, H. S. Jung and M. Choi, Energy Environ. Sci., 2017, 10, 337.

27 H. Sung, N. Ahn, M. S. Jang, J. Lee, H. Yoon, N. Park and M. Choi, Adv. Energy Mater., 2016, 6, 1501873.

28 I. Jeon, J. Yoon, N. Ahn, M. Atwa, C. Delacou, A. Anisimov, E. I. Kauppinen, M. Choi, S. Maruyama and Y. Matsuo, J. Phys. Chem. Lett., 2017, 8, 5395.

29 B. Kumanek and D. Janas, J. Mater. Sci., 2019, 54, 7397-7427.

30 I. Jeon, C. Delacou, H. Okada, G. E. Morse, T.-H. Han, Y. Sato, A. Anisimov, K. Suenaga, E. I. Kauppinen, S. Maruyama and Y. Matsuo, J. Mater. Chem. A, 2018, 6, 14553.

31 M. Savchak, N. Borodinov, R. Burtovyy, M. Anayee, K. Hu, R. Ma, A. Grant, H. Li, D. B. Cutshall, Y. Wen, G. Koley, W. R. Harrell, G. Chumanov, V. Tsukruk and I. Luzinov, ACS Appl. Mater. Interfaces, 2018, 10, 3975.

32 E. Lee, J. Ahn, H.-C. Kwon, S. Ma, K. Kim, S. Yun and J. Moon, Adv. Energy Mater., 2018, 8, 1702182.

33 B. Li, S. Ye, I. E. Stewart, S. Alvarez and B. J. Wiley, Nano Lett., 2015, 15, 6722.

34 Y. Zhang, J. Guo, D. Xu, Y. Sun and F. Yan, ACS Appl. Mater. Interfaces, 2017, 9, 25465.

35 L. Lan, T. Yin, C. Jiang, X. Li, Y. Yao, Z. Wang, S. Qu, Z. Ye, J. Ping and Y. Ying, Nano Energy, 2019, 62, 319.
36 S. Lin, H. Wang, X. Zhang, D. Wang, D. Zu, J. Song, Z. Liu, Y. Huang, K. Huang, N. Tao, Z. Li, X. Bai, B. Li, M. Lei, Z. Yu and H. Wu, Nano Energy, 2019, 62, 111.

37 S. Kang, J. Jeong, S. Cho, Y. J. Yoon, S. Park, S. Lim, J. Y. Kim and H. Ko, J. Mater. Chem. A, 2019, 7, 1107.

38 S. Hong, H. Lee, J. Lee, J. Kwon, S. Han, Y. D. Suh, H. Cho, J. Shin, J. Yeo and S. H. Ko, Adv. Mater., 2015, 27, 4744.

39 J. H. Cho, D. J. Kang, N.-S. Jang, K.-H. Kim, P. Won, S. H. Ko and J.-M. Kim, ACS Appl. Mater. Interfaces, 2017, 9, 40905.

40 H. Lee, I. Kim, M. Kim and H. Lee, Nanoscale, 2016, 8, 1789.

41 Y. J. Lee, Y. Lee, D. Oh, T. Chen, G. Ceder and A. M. Belcher, Nano Lett., 2010, 10, 2433.

42 R. A. Blaik, E. Lan, Y. Huang and B. Dunn, ACS Nano, 2016, 10, 324.

43 Y. Lee, J. Kim, D. S. Yun, Y. S. Nam, Y. Shao-Horn and A. M. Belcher, Energy Environ. Sci., 2012, 5, 8328.

44 X. Dang, H. Yi, M.-H. Ham, J. Qi, D. S. Yun, R. Ladewski, M. S. Strano, P. T. Hammond and A. M. Belcher, Nat. Nanotechnol., 2011, 6, 377.

45 K. T. Nam, Y. J. Lee, E. M. Krauland, S. T. Kottmann and A. M. Belcher, ACS Nano, 2008, 2, 1480.

46 B. R. Peelle, E. M. Krauland, K. D. Wittrup and A. M. Belcher, Langmuir, 2005, 21, 6929.

47 P. Selvakannan, A. Swami, D. Srisathiyanarayanan, P. S. Shirude, R. Pasricha, A. B. Mandale and M. Sastry, Langmuir, 2004, 20, 7825.

48 Y. Liu, Y. Chen, R. Shi, L. Cao, Z. Wang, T. Sun, J. Lin, J. Liu and W. Huang, RSC Adv., 2017, 7, 4891.

49 H. Ding, Y. Zhang, G. Yang, S. Zhang, L. Yu and P. Zhang, RSC Adv., 2016, 6, 8096.

50 H. C. Brown and B. C. S. Rao, J. Am. Chem. Soc., 1956, 78, 2582.

51 D. Todd, J. Chem. Educ., 1979, 56, 540.

52 A. Gharatape, S. Davaran, R. Salehi and H. Hamishehkar, RSC Adv., 2016, 6, 111482.

53 J. H. Billman and J. W. McDowell, J. Org. Chem., 1961, 26, 1437.

54 M. Wojnicki, E. Rudnik, M. Luty-Błocho, K. Pacławski and K. Fitzner, Hydrometallurgy, 2012, 43, 127.

55 U. Sanyal and B. R. Jagirdar, Inorg. Chem., 2012, 51, 13023. 56 S. Joly, R. Kane, L. Radzilowski, T. Wang, A. Wu, R. E. Cohen, E. L. Thomas and M. F. Rubner, Langmuir, 2000, 16, 1354.

57 F. Kim, K. Sohn, J. Wu and J. Huang, J. Am. Chem. Soc., 2008, 130, 14442.

58 B. P. Khanal and E. R. Zubarev, ACS Nano, 2019, 13, 2370.

59 N. R. Jana, L. Gearheart and C. J. Murphy, J. Phys. Chem. B, 2001, 105, 4065.

60 J. Rodríguez-Fernández, J. Pérez-Juste, F. J. García de Abajo and L. M. Liz-Marzán, Langmuir, 2006, 22, 7007.

61 C. J. Ward, R. Tronndorf, A. S. Eustes, M. L. Auad and E. W. Davis, J. Nanomater., 2014, 1.

62 C. L. John, S. L. Strating, K. A. Shephard and J. X. Zhao, RSC Adv., 2013, 3, 10909.

63 B. Zümreoglu-Karan, J. Nanopart. Res., 2009, 11, 1099.

64 M. M. T. Khan and A. E. Martell, J. Am. Chem. Soc., 1967, 89, 4176. 
65 L. Malassis, R. Dreyfus, R. J. Murphy, L. A. Hough, B. Donnio and C. B. Murray, RSC Adv., 2016, 6, 33092.

66 H. Kang, J. T. Buchman, R. S. Rodriguez, H. L. Ring, J. He, K. C. Bantz and C. L. Haynes, Chem. Rev., 2019, 119, 664.

67 N. E. Larm, J. A. Thon, Y. Vazmitsel, J. L. Atwood and G. A. Baker, Nanoscale Adv., 2019, 1, 4665.

68 E. Alegria, A. Ribeiro, M. Mendes, A. Ferraria, A. do Rego and A. Pombeiro, Nanomaterials, 2018, 8, 320.

69 J. Haber and K. Sokolov, Langmuir, 2017, 33, 10525.

70 E. G. Wrigglesworth and J. H. Johnston, RSC Adv., 2017, 7, 45757.

71 M. N. Martin, J. I. Basham, P. Chando and S.-K. Eah, Langmuir, 2010, 26, 7410.

72 P. Suchomel, L. Kvitek, R. Prucek, A. Panacek, A. Halder, S. Vajda and R. Zboril, Sci. Rep., 2018, 8, 4589.

73 C. Lin, K. Tao, D. Hua, Z. Ma and S. Zhou, Molecules, 2013, 18, 12609.

74 M. Dasog, W. Hou and R. W. J. Scott, Chem. Commun., 2011, 47, 8569.

75 N. S. K. Gowthaman, B. Sinduja and S. A. John, $R S C A d v$, 2016, 6, 63433.

76 P. J. Rivero, J. Goicoechea, A. Urrutia and F. J. Arregui, Nanoscale Res. Lett., 2013, 8, 101.

77 K. T. Nam, R. Wartena, P. J. Yoo, F. W. Liau, Y. J. Lee, Y.-M. Chiang, P. T. Hammond and A. M. Belcher, Proc. Natl. Acad. Sci. U. S. A., 2008, 105, 17227.

$78 \mathrm{Au}$ XPS Reference from Cardiff University, can be found under http://sites.cardiff.ac.uk/xpsaccess/reference/gold/.

79 J. Radnik, C. Mohr and P. Claus, Phys. Chem. Chem. Phys., 2003, 5, 172.
80 M. Sankar, Q. He, M. Morad, J. Pritchard, S. J. Freakley, J. K. Edwards, S. H. Taylor, D. J. Morgan, A. F. Carley, D. W. Knight, C. J. Kiely and G. J. Hutchings, ACS Nano, 2012, 6, 6600.

81 C. Han, L. Ge, C. Chen, Y. Li, Z. Zhao, X. Xiao, Z. Li and J. Zhang, J. Mater. Chem. A, 2014, 2, 12594.

82 C. A. Strydom, J. F. van Staden and H. J. Strydom, J. Electroanal. Chem. Interfacial Electrochem., 1990, 277, 165.

83 P. Parent, J. Lasne, G. Marcotte and C. Laffon, Phys. Chem. Chem. Phys., 2011, 13, 7142.

84 J. Yang, Y. Zhao, J. Zhang and C. Zheng, Fuel, 2016, 167, 366. 85 D. Dong, Y. Zhang, S. Sutaria, A. Konarov and P. Chen, PLoS One, 2013, 8, e82332.

86 J. Ma and M. Zhan, RSC Adv., 2014, 4, 21060.

87 J. Huang, C. Ding, Y. Yang, G. Liu and W.-B. Cai, Chin. J. Catal., 2019, 40, 1895.

88 I. Jeon, S. Zeljkovic, K. Kondo, M. Yoshizawa and Y. Matsuo, ACS Appl. Mater. Interfaces, 2016, 8, 29866.

89 A. Kim, H. Lee, H. C. Kwon, H. S. Jung, N. G. Park, S. Jeong and J. Moon, Nanoscale, 2016, 8, 6308-6316.

90 H. Hwang, J. Ahn, E. Lee, K. Kim, H. C. Kwon and J. Moon, Nanoscale, 2017, 9, 17207-17211.

91 K. Kim, H. C. Kwon, S. Ma, E. Lee, S. C. Yoon, G. Jang, H. Yang and J. Moon, ACS Appl. Mater. Interfaces, 2018, 10, 30337.

92 Y. Jin, Y. Sun, K. Wang, Y. Chen, Z. Liang, Y. Xu and F. Xiao, Nano Res., 2018, 11, 1998.

93 H. Dong, Z. Wu, Y. Jiang, W. Liu, X. Li, B. Jiao and X. Hou, ACS Appl. Mater. Interfaces, 2016, 8, 31212-31221.

94 H. Chen, M. Li, X. Wen, Y. Yang, D. He, W. C. Choy and H. Lu, Nanomaterials, 2019, 9, 193. 